\title{
Work-life Balance: Societal and Private Influences*
}

\author{
VĚRA KUCHAŘOVÁ** \\ Research Institute for Labour and Social Affairs, Prague
}

\begin{abstract}
This article is intended to contribute to the discussion about the possibilities for supporting work-life balance. It has two basic objectives. The first is to assess the dependence of work-life balance on economic conditions and the character of the given welfare/family regime. The second is to evaluate how much work-life balance is influenced by private-life determinants and how much by external, that is, structural and institutional, factors. The analysis is based on a comparison of the situation in the Czech Republic with selected countries. Success at achieving a work-life balance is examined both from a subjective perspective and in relation to the three basic social goals it is intended to facilitate: women's employment, people's reproductive plans, and gender equality. An international comparison shows that while the forms and success of harmonising family and professional roles in countries with different external factors have specific national features, people's subjective assessments of their ability to combine these two spheres of activity vary little among economically active partners. The reason for this appears to be that to some extent people adapt (more or less voluntarily) their harmonisation strategies to the external conditions in individual countries. Also, these strategies are influenced by national socio-cultural specifics and differences in the degree of acceptance of gender inequalities.
\end{abstract}

Keywords: work-life balance, employment, reproductive behaviour, gender equality, family regime

Sociologický časopis/Czech Sociological Review, 2009, Vol. 45, No. 6: 1283-1310

The importance of work-life balance tends to be highlighted in three contexts. One context is employment and the political interest of generally increasing employment and especially women's labour-market participation [Benn and Kvist 2007; Crompton and Lyonette 2006; Kotowska and Matysiak 2008]. Gender relations and the promotion of gender equality at work and in the family are the second context [Hakim 2000; Work-life Balance 2007; Kř́žzová (ed.) 2006]. The third context relates to reproductive behaviour and specifically fertility as a means of off-

\footnotetext{
* This article was prepared as part of work on the project 'Active Ageing, Family, and Intergenerational Solidarity' (registration no. 2D06004) of the National Research Programme II, supported by the Ministry of Education, Youth and Sport of the Czech Republic.

** Direct all correspondence to: Věra Kuchařová, Research Institute for Labour and Social Affairs, Palackého n. 4, 12801 Prague 2, Czech Republic, e-mail: vera.kucharova@vupsv. cz.
} 
setting population ageing [Neyer 2006; Kocourková and Rabušic 2006; Gauthier and Philipov 2008; Botev 2008; Thévenon 2008]. The interest and significance attached to work-life balance is enhanced by the fact that its declared (political) objectives can prove to be mutually incompatible. In a macro-social perspective, this is where the particular interests of population growth, economic prosperity, and human rights tend to collide. On the individual level, it is where the parental and professional aspirations of people clash. Originally a private concern, the need to combine family and professional roles has become a political issue, which was first brought to light in connection with the issue of equal opportunities. Today, it is an interdepartmental issue that figures on the government's policy agenda, and in the Czech Republic a key role is played by the substance and tools of family policy [Kocourková and Rabušic 2006: 116 ff.; Národní 2005]. As with any political issue, questions are raised about the effectiveness of the tools used to achieve declared objectives, so it is essential to know which factors help people successfully achieve a work-life balance and how much this success can actually be influenced by family and other policies.

The goals and strategies of work-life balance derive from both the public and the private spheres, and the outcome of efforts to achieve this balance can be evaluated from two perspectives: personal satisfaction and the fulfilment of established social objectives. These two perspectives are essentially intertwined. Therefore, this article focuses on two questions: a) how well do individuals succeed in harmonising their family and professional aspirations in different structural circumstances, and b) how much is the harmonisation of these two spheres of life influenced by personal, subjective, and private factors, or conversely, how big an influence are external, for instance, structural and institutional, factors.

The political objective of supporting women's participation in the labour market is less of a priority in the Czech Republic because compared to other countries the employment rate of Czech women has in the long run been consistently high [Večerník 2009]. Nevertheless, in international comparisons, the Czech Republic tends to rank with countries in which society's support for work-life balance has in this respect been ineffective [OECD Family Database 2007; Babies and Bosses 2007; Gauthier and Philipov 2008; Kř́žzová (ed.) 2006]. According to the OECD, the employment rate of Czech women aged 25-44 is above the average of OECD countries, but the Czech Republic has one of the lowest rates of employment of mothers with dependent children (up to the age of 16), ranking it among countries in Central and Southern Europe. Compared to most of the countries in that group, however, the Czech Republic does have a higher employment rate of mothers with children over the age of 6 . The reason for this is that it provides families with small children with relatively generous financial support [Švarc and Švarcová 2007: 16; Gauthier and Philipov 2008: 8 ff.]. However, owing to this support, the Czech social system is imputed to have a strongly de-motivating influence on women's employment. This somehow simplifies the understanding of the role of family and social policy measures, as this role also depends on 
the legitimacy of the measures implemented, the situation in the labour market, and available work flexibility arrangements. Moreover, the objectives (concepts) of various policies applied at a given time can come into conflict. For example, at the start of the 1990s, the parental allowance was designed as a tool to support care for children at home and as an alternative to employment. Later, these aspects of its design were questioned in connection with the objectives of women's employment and gender equality. Part of what has contributed to greater gender inequality is that despite the fact that new measures were introduced to encourage men to take parental leave they have not been doing so. It seems that the desired outcome of creating the institutional conditions for a work-life balance need not be attained if they are in conflict with individual (subjective) needs.

This article is aimed at providing a deeper understanding of the relationship between the societal and private determinants of work-life balance. It analyses the effect of external factors primarily on the basis of international comparisons. Published findings from the international 'Generations and Gender Survey' and its database are used (GGS 2005; see the Appendix). To assess the influence of individual and subjective factors, Czech data from empirical surveys conducted as part of the 2006 'Family, Work, Education' project are used.

The article opens with a brief summary of the conceptual bases justifying the need for and the direction of analysis of the complementarity of the private and societal determinants of work-life balance. This is followed by an assessment of the role of structural factors based on an international comparison. Attention then turns to significant private determinants, in particular the relationship between economic activity and the gender division of labour in the family. The closing summary presents a discussion of the relationship between individual and external factors from the perspective of the degree and 'success' of work-life balance and the specific features of the relationship between the two in the Czech Republic.

\section{Basic concepts}

Contemporary scholarship offers various stimuli for studying the significance of the external (societal) and personal (private) factors conducive to maintaining a balance between family and professional roles. At the individual level, there are three important concepts that tend to be used to analyse the relationship between family and professional roles and the degree to which these two spheres conflict. The first is preference theory and the concept of value orientations [Hakim 2000; Rabušic and Chromková Manea 2007]. The second is the perspective of the time use of employees caring for children (or other family members) and the division of roles between men and women [Benn and Kvist 2007; Edlund 2007; Maříková 2008]. The third approach is to examine the phenomenon in the context of the life course [Gershuny 2003; A New Organisation 2003; Hoem 2006; Kř́žžková (ed.) 
2006; Modernising 2007]. Each of these concepts in its own way provides evidence of how significantly work-life balance is determined by personal aspirations and value orientations.

Gender differences run through all three of these concepts. The double shift and the three-phase life cycle are still the norm for women in Czech society - and elsewhere - despite major shifts in people's opinions towards showing more support for equal opportunities. Today, the strategies working women adopt to achieve a work-life balance and the related behaviour of their partners are for the most part various modifications of a liberal approach [Možný 2008: 170], which tends to be shaped by both subjective and institutional influences [Kotowska and Matysiak 2008: 305; Kuchařová et al. 2009b]. This approach is apparent both in people's life strategies (the life course) and in the way they divide their time between family responsibilities and work over the course of the day and thus in the division of roles between partners. This approach also influences people's decisions about whether and when they plan to have a family. Modern society has seen a change in the relationship between women's employment and motherhood, which in itself has been transforming both in terms of 'intensity' (the number of children a woman has) and quality (how a woman performs her role as a mother and how this role relates to other roles in a woman's life). But the complicated relationship between the spheres of work and family is not just a problem for women. For men, efforts to achieve a work-life balance have been directed at their greater involvement in the family [The Social 2006; Edlund 2007], with 'new active fatherhood' being one means of achieving this balance. The fact that 'active fatherhood' has failed to catch on more widely in the Czech Republic [Mař́iková and Vohlídalová 2007; Nešporová 2005, 2007] and that it is more a response to the weakening role of the father in the family [cf. Možný 1990; Sullerot 1998; de Singly 1999] has drawn criticism. Other, less common forms of balancing the roles of men and women at home and at work, such as the revival of the 'family business', play a smaller role. Conversely, T. Sirovátka [2006: 98] has noted that support for the greater involvement of fathers in the family need not always and in every case have a positive effect - while it is important for gender equality, it might not be conducive to encouraging the employment of women.

In a global context, modernisation determines the structural and institutional conditions of work-life balance and it can be viewed from two angles. On the one hand, the positive effects of modernisation can be seen in how work has become easier and less physically demanding and working hours shorter, in how unpaid work has become less time-demanding, in how the life cycles of men and women have become more alike, and in the greater amount of free time [Gershuny 2000; Gershuny 2003: $4 \mathrm{ff}$.]. On the other hand, since roughly the middle of the 20th century, the demands of work and family life have been at clear odds. With more opportunities in life and greater mobility, people focus more on consumption, and their demands become more sophisticated, and this puts more pressure on their economic activity. Compared to more advanced countries, modernisa- 
tion trends in the Czech Republic and other ex-communist countries are more obviously negative: the amount of time devoted in total to paid and unpaid work is growing, as is the gap between individuals' consumer demands and their ability to satisfy them. It can be assumed that the negative features of modernisation add to the conflict between the family and work. What is an especially overt effect of modernisation is the impact that the difficulty of achieving a work-life balance has on fertility. Today, however, the higher employment rate of women does not have to be an obstacle to women's career plans, and on the contrary, in countries where women's employment rates are higher, fertility also tends to be higher [Sirovátka 2006; Křižková (ed.) 2006; Benn and Kvist 2007; Thévenon 2008]. That is why the core objective of family and social policy is to find new ways of supporting families and reconciling their commitments with the demands of work.

After falling slightly, the employment rate of women in the Czech Republic has remained consistently high, but even the rise in fertility in recent years has not offset the sharp decline that occurred in the 1990s [Rychtař́ková 2008: 12 an.; Sobotka et al. 2008: 447]. Developments today have their roots in the break in continuity of modernisation that occurred when the Czech Republic (Czechoslovakia) was part of the Eastern bloc, which for a long time altered the direction of development of the family [Možný 2003] and the relationship between the family and the public sphere, leading the family to close in on itself. After 1989 one reaction to this situation was greater individualisation, the consequences of which altered family behaviour [Mař́ková 2000], the life cycle, and the family cycle [Hamplová, Šalamounová and Šamanová 2006], and the spectrum of people's interests and activities also grew as a result [Matějů and Večerník 1998]. Parenthood and gender relations, and their values and forms, are gradually changing, but the family is still highly valued. Some discontinuity can be discerned from how the institutional background to these changes developed and from the policies designed to support families and employment [Thévenon 2008; Nešporová 2006].

Views vary between countries as to whether reconciling family and work commitments is primarily a private concern, a matter for each family itself, or whether it is a social problem, in which case the responsibility lies with the government and other institutions. Generally, in the more market-oriented AngloSaxon countries, emphasis is placed on the private nature of the issue; in Scandinavian countries it is viewed more as a political issue. It is interesting that in both of these regions we find countries in which the employment rate of women is high and the fertility rate is also relatively high. The basic objectives of worklife balance are thus being striven for in different structural conditions and welfare regimes, so there must be other influential factors. These could be private factors present across different countries or socio-cultural factors specific to one particular country. Although institutional conditions are key to achieving a worklife balance [cf., e.g., Lewis, Campbell and Huerta 2008; D'Addio and D'Ercole 2005; Sirovátka 2006; A New Organisation 2003], how they influence family life is not straightforward [de Singly 1999; Chorvát 2006]. By assuming a number of 
traditional family functions, institutions on the one hand help create a smoother relationship between the private and public spheres, but on the other hand they interfere in the autonomy of the family. This is typified by the discussion about access to day-care for small children as an effective tool for reconciling work and family, a discussion prompted, among other things, by the Barcelona objectives [Lewis, Campbell and Huerta 2008; D'Addio and D'Ercole 2005; Sirovátka 2006]. However, support for institutional day care is challenged by the advocates of maternal (parental) care.

One of the basic structural conditions for combining work and family activities is the situation in the labour market and working conditions. Without taking this into account, the influence of other external factors cannot be accurately assessed [cf. Benn and Kvist 2007; Lewis, Campbell and Huerta 2008: 34; Edlund 2007: 473]. However, the employment and unemployment rates alone form just a general frame for the decisions people make - including mothers of small children - about whether to work and whether they should work full time. An important role is played by the approach taken by employers, that is, by their human resources policies, by corporate culture, and by what kind of flexible working hours an employer offers [Kangas and Rostgaard 2007; Kotowska and Matysiak 2008]. For example, part-time hours, when they are an option that is widely enough available, extend the selection of strategies for fulfilling family and professional ambitions. Their limited availability in the Czech Republic has had the opposite effect. The same is true of flexible working hours. According to empirical data, in the Czech Republic [Organizace 2005; Kuchařová et al. 2006b], like in many other EU countries [Hardarson 2007; Lewis, Campbell and Huerta 2008], there is a relatively small share of women with young children who have flexible working hours.

Institutional conditions are currently changing together with changes in the family and the two trends are intersecting. On the one hand, the family is becoming more autonomous, and on the other it is becoming more dependent on the institutional environment. The problem of harmonising family and professional roles first arose as the nuclear family began to be independent [Možný 2008; Chorvát 2006: 12], the private and public spheres separated, and the process of individualisation set in [Berger and Berger 1983; de Singly 1999]. The tension between family and work roles grew as the ties of inter- and intra-generational solidarity in the wider family weakened and progressed interdependently with the development of the welfare state. The role of the welfare state then (potentially) grew as the nuclear family's ability to draw on support from the extended family decreased [Možný 2003]. Forms of social assistance based on the family, which promote the complementarity of gender roles [Možný 2008: 176] and concentrate on supporting family income, are less effective today because they fail to respect the emancipative efforts of women and the general shift in values [Esping-Andersen 2002; Kotowska and Matysiak 2008]. Demographic changes together with the advancement of gender discourse and support for women's employment thus 
create a heterogeneous framework in which it is necessary to seek a balance between the spheres of work and private life.

Institutional and structural changes also lead to changes in the staging of the life course [cf. Gershuny 2003; Haberlová and Kuchařová 2008] and affect the decisions made at key moments in the life and family cycle of an individual. It is at these moments that private and external factors come into conflict. Marshall and Mueller [A New Organisation 2003: 18] have written about the institutionalisation of the life cycle in modern society. Institutions have either a constraining or supportive influence on decisions (e.g. educational institutions through the extent of available childcare, employers' organisations by means of working hours and pay, and social security systems by the degree to which they intervene in the family). As opposed to the past, today the life cycle is more strongly affected by economic circumstances (the labour market), while comparatively family events are rather waning in significance [cf. Možný 2008; Edlund 2007; Modernising 2007]. The life courses of men and women ought to be increasingly alike, but in reality this only applies to some social groups.

Assessing the significance of personal and external determinants of worklife balance essentially means assessing how these determinants affect the success of this balance. There are three ways of defining this success: a) what is the subjective perception of the relationship between these two spheres, b) what strategies do people prefer and what strategies do they really use to combine work and family roles, and c) how well are the societal goals that work-life balance is meant to facilitate being met. As mentioned above, these relate to work, parenthood, and gender equality.

\section{International comparisons of the conditions of work-life balance}

What the above discussion reveals is that in a macro-social perspective the external determinants of work-life balance are influenced by the degree of modernisation (economic development) in society and by government policies. The former can be assessed, for instance, by a society's wealth or GDP, social stratification (inequality in incomes, education), or the rate of (un)employment. As regards government policies, the key role is played by family and social policy and by the equal opportunities policy in a country. These are summarily labelled as a given 'family regime' or 'family welfare'. Family regime variations can largely be explained by the differences in the way similarly advanced (modernised) countries achieve a work-life balance. Theories on family regimes distinguish between market-oriented countries, familialistic countries, and de-familialistic countries [cf. Esping-Andersen 2002]. The changing post-socialist countries, which are still formulating their respective family policies, tend to be described as having re-familialistic regimes [Matějková and Paloncyová 2005: 14; Sirovátka 2006]. International comparisons of work-life balance and phenomena (presumably) influenced 


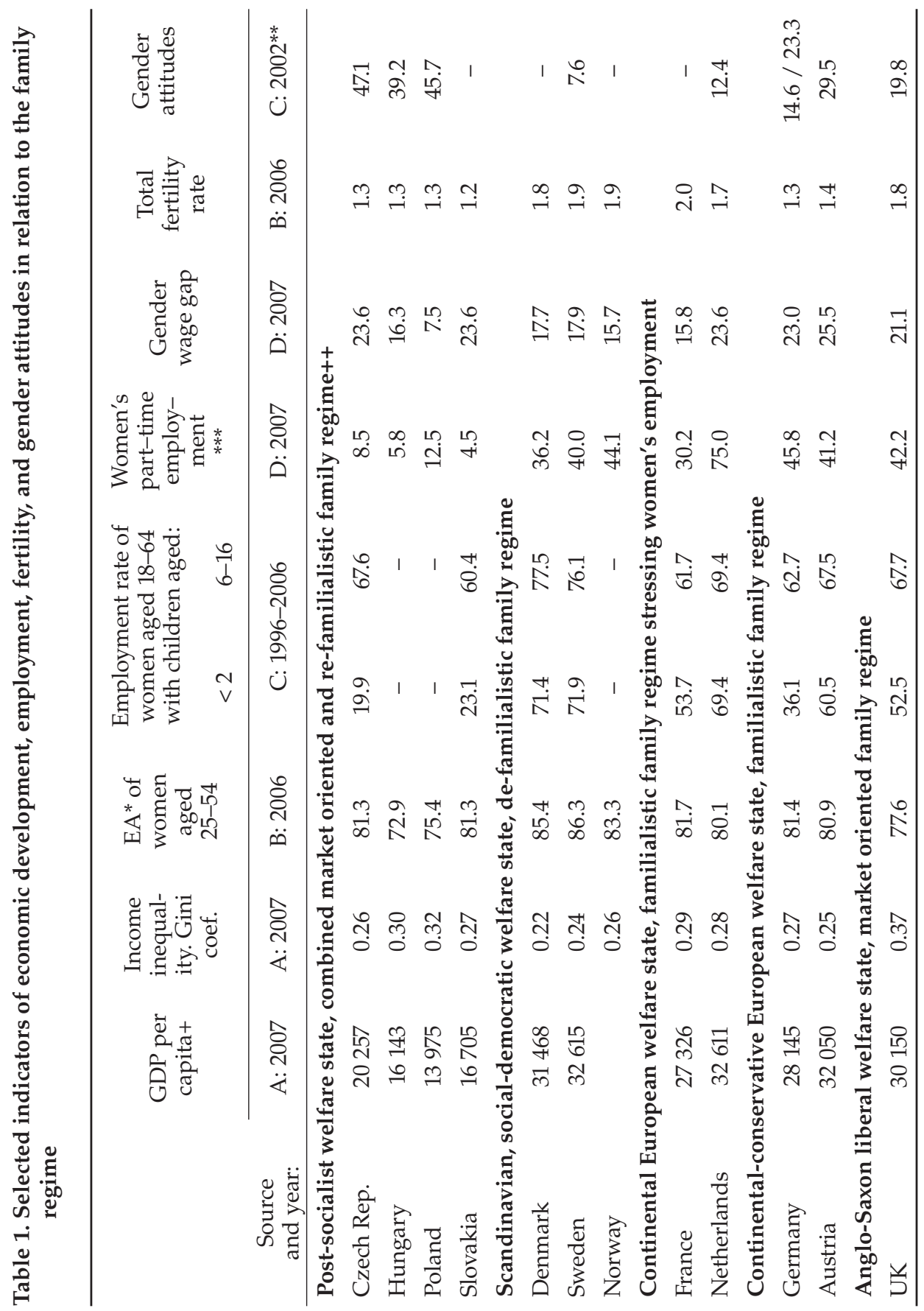




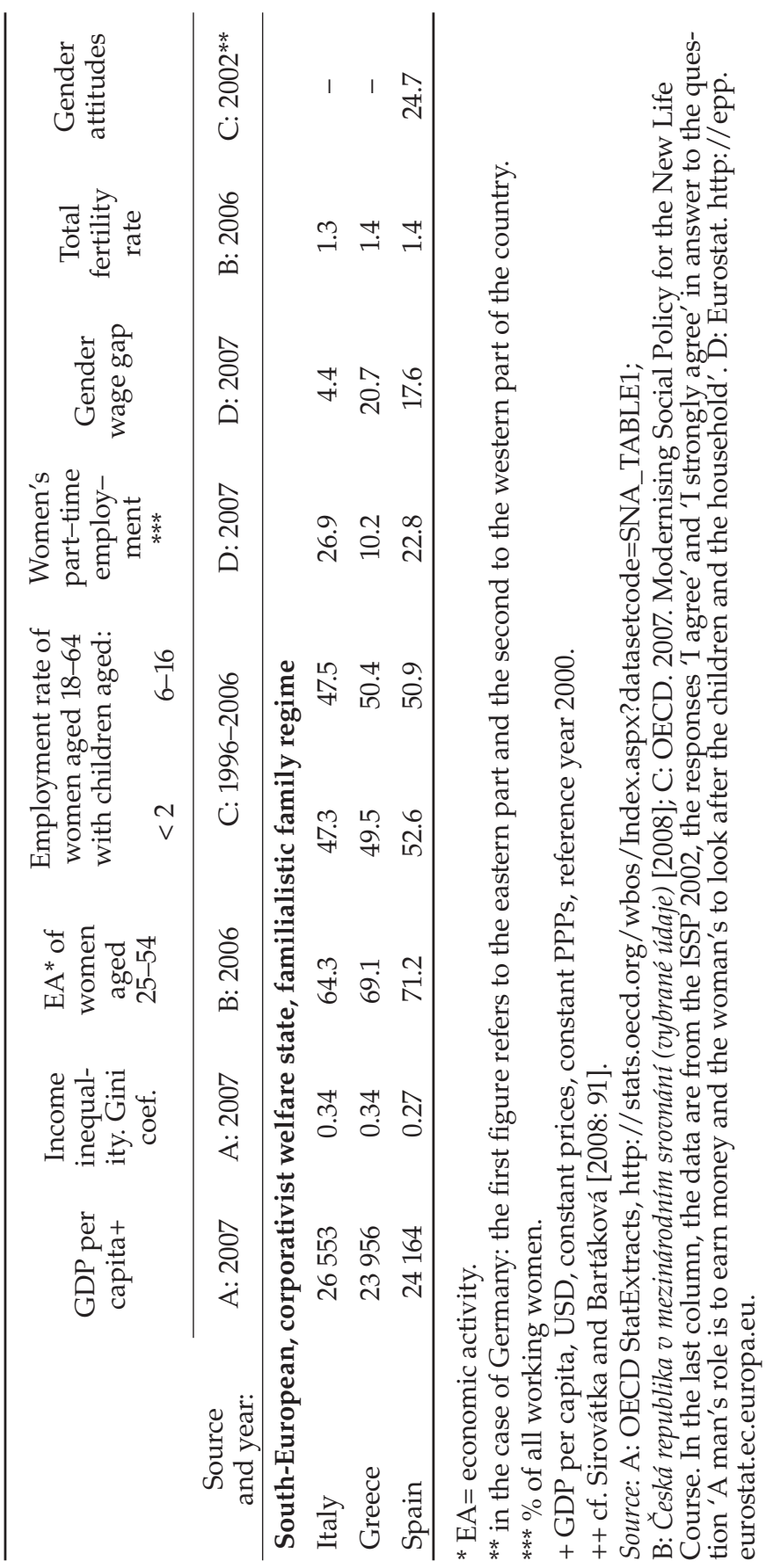


by the success of this balance (such as fertility and women's employment) have revealed the de-familialistic model of Nordic countries to be the most successful [e.g. Gauthier and Philipov 2008; Crompton and Lyonette 2006: 389]. However, some authors have noted that the relationship between a successful work-life balance and the nature of a given family regime (like the degree of modernity) is not straightforward.

Table 1 compares selected indicators of the effectiveness of work-life balance (fertility and women's employment) in different countries with selected external factors characterising the degree of economic development in society and with indicators of gender differences. The countries are also grouped by type of family and social policy (with the understanding that no pure types exist in reality). The table shows that various 'types' of family behaviour occur within each type of family regime. Among countries grouped as regions in Europe that share a particular type of welfare state there are differences in fertility rates, and conversely, there are similar fertility rates among countries that belong to different types of family regime.

An analogical conflict applies to how well people are able to balance work and family roles (work-life conflict) [Edlund 2007; Gauthier and Philipov 2008]. Among the countries of Western Europe, for instance, less work-life conflict is observed in 'familialistic' Austria than in the Nordic countries, including the countries most successful at maintaining a work-life balance (Denmark and Finland). Findings vary between the individual Nordic countries. Conversely, there are features in common in countries from different regions. For example, the Czech Republic and Sweden are very much alike in terms of the success with which they are able to facilitate a balance between work and family responsibilities, and similar to them are France, with its generous family policy, and even the liberally inclined UK [Edlund 2007].

Survey data also prove a less clear relationship between work-life balance indicators and the indicators of socio-economic and socio-political conditions in countries with certain 'types' of family regime. J. Edlund [2007: 455 ff.], for example, has closely studied the level of work-life balance in countries at different stages of (economic) development and with different family regimes. In his comparison, which focused on dual-earner couples, countries varied by the share of each of three clusters defined according to the degree to which people are able to cope with the conflict between work and family (using 'latent class analysis'). In his analysis, contrary to expectations, de-familialistic countries do not have the highest level of work-life balance (as findings would otherwise suggest [Crompton and Lyonette 2006]). Some post-socialist countries (Czech Republic, Hungary, Slovenia) are not lagging significantly behind Western European countries (both market-oriented and familialistic) and have somewhat better 'results' than familialistic countries in Southern Europe and the '(pro)family regimes' in other countries of Central and Eastern Europe. In this comparison, the Czech Republic ranks with countries in which the conflict between work and family is 
not considered to be too severe, and at the same time with countries in which potential tension stems mainly from the demands of work. However, many analyses have described the conditions in the Czech Republic as not conducive to helping people fulfil both work and family roles [see also Feasibility Study 2002; Babies and Bosses 2007].

Despite the differences in the degree to which people in advanced countries manage to achieve a work-life balance, for the most part they nonetheless do so. This fact raises the question of how they manage to do so and how free they are to choose their strategies. J. Edlund [2007] offers one possible explanation by pointing out that in some countries with a successful work-life balance just a small share of mothers of very young children work. It can be assumed that those for whom combining work and family responsibilities would be hard to manage are absent from the labour market. This is something that can be observed, for instance, in the Czech Republic. The basic strategies for reconciling family and professional ambitions, that is, for dividing time between these two spheres, conform to two basic outlooks: one is a life-long perspective (as already mentioned), and the other is a daily perspective. In other words, the former relates to the economic (in)activity of partners in different stages of the family cycle, and the latter to the division of labour between partners. As regards the latter, today the general trend is moving away from the male breadwinner model (corresponding to the familialistic family regime) towards the dual-earner model (prevailingly in de-familialistic regimes). However, this shift is occurring very unevenly across European countries, regardless of the generally rising rate of women's employment [Kotowska and Matysiak 2008; Sirovátka and Bartáková 2008; Saraceno 2009]. Opinions on the degree to which the male breadwinner model is adopted voluntarily vary, and some experts refer to the intentional choice of this option (in the sense of a targeted return to traditions) as a fourth model.

I. E. Kotowska and A. Matysiak [2008] worked out an international comparison of preferred and real models of work-life balance in relation to family structure. They examined the preferences for three models of the division of roles between partners. Alongside the male breadwinner model and the dual-earner model, the third is the modernised male breadwinner model (in which the man works full time and the woman part time). The authors studied whether these models are contingent on different welfare/family regimes. Although in all of the countries studied (except the Netherlands) the dual-earner model prevailed in reality, countries varied by the degree of prevalence and did so in relation to the availability and use of opportunities for part-time employment. In many countries the male breadwinner model and the modernised male breadwinner model apply more often against people's preferences [Kotowska and Matysiak 2008: 308; see also Lewis, Campbell and Huerta 2008]. Which strategic division of roles between partners is selected does not seem to be an altogether free choice and, on the contrary, external structural-institutional factors appear to be of some significance. This is supported by Figure 1 (constructed with other survey data), which 
Figure 1. Combinations of full-time and part-time work between partners in the family, aged 20-49 (at least one partner working)

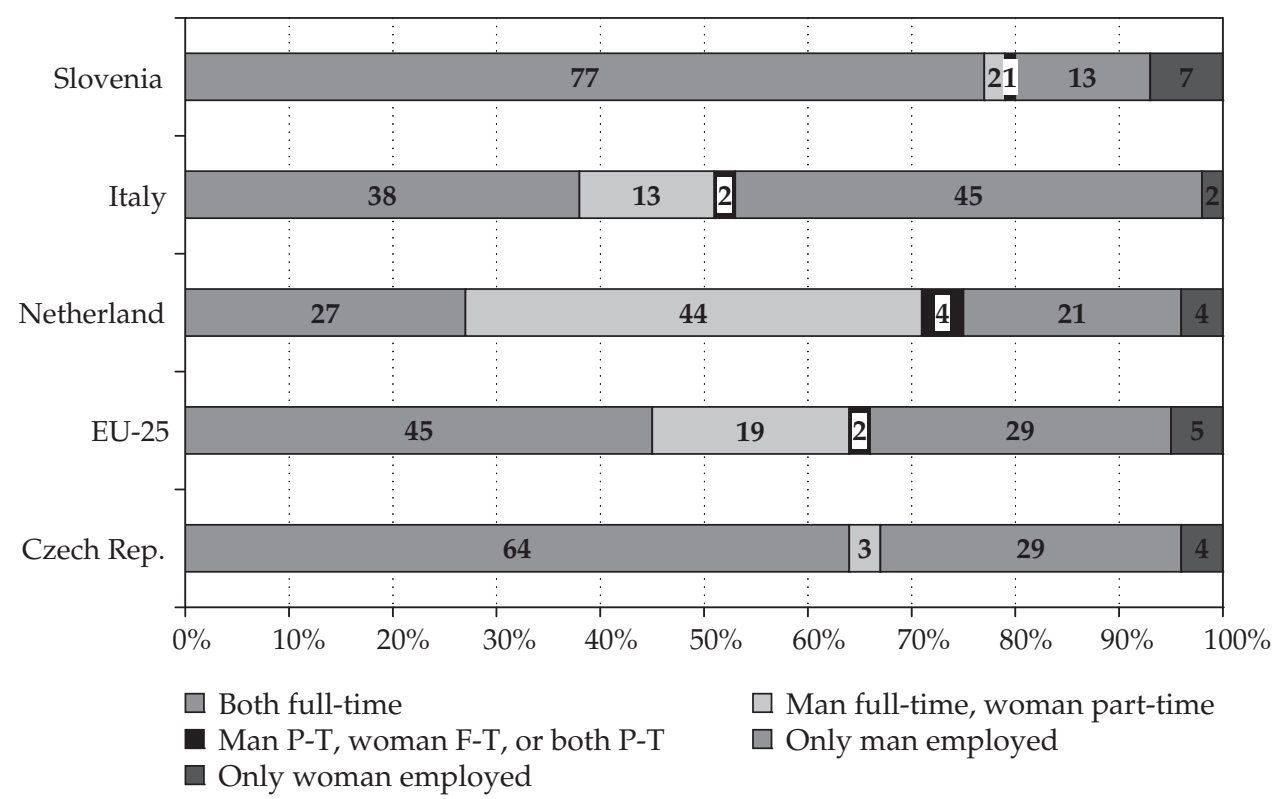

Notes: $\mathrm{P}-\mathrm{T}=$ part-time; F-T $=$ full-time.

Source: A New Organisation of Time over Working Life [2003: 92].

in the interest of clarity presents only the European countries most at variance. It illustrates the difference between Italy (representing the familialistic family regime), Slovenia (supporting women's employment), and the Netherlands with its specific tradition of a large share of women working part time. Is it certain, however, that structural factors are the primary influence here? These (and other) countries also vary by their socio-cultural features, which influence the concept of family roles and the division of work in the family between partners.

\section{Assessing societal and private influences in selected countries}

From the above we can formulate the hypothesis that the conditions for achieving a work-life balance are largely determined by structural-institutional factors, but the degree to which this is so depends on the strength of influence of specific private determinants. These determinants include the personal disposition and preferences of individuals in their life goals. These derive partly from characteristics specific to each country and have an effect on the harmonising strategies people choose at important periods in the life cycle. In the sections below we 
will test this hypothesis and determine how the situation in the Czech Republic may differ in terms of the obstacles that exist to achieving a work-life balance. An international comparison will be used to assess the specific features of the relationship between these spheres in countries with different external conditions, and these will be contrasted with the influence of individual, including family, disposition. While the assumption that the factors behind an individual's particular situation are determined by the socio-cultural specifics of individual countries is not explored in detail here, we will examine whether personal characteristics (disposition) changes over the course of an individual's life course.

In this section, we use data from the Generations and Gender Survey (GGS). The GGS was carried out as part of an international research programme of the UN's Economic Commission, and at present data are available for Bulgaria, France, Georgia, Hungary, Germany, and the Netherlands, as well as the Czech Republic (for more, see the References). The countries whose data are used here were thus not selected deliberately by the author but are determined by the availability of data. Nevertheless, the selection contains countries at varying stages of economic development and with different family regimes. The key questions about combining work and family activities are analysed for just four countries, because only they provided the relevant data.

This analysis of how 'successful' people are at combining work and family roles is based on responses to a battery of questions customarily used in international surveys [e.g. Edlund 2007; Second 2009]. The questions measure the degree of conflict between family and work roles. Respondents were asked how often in the recent period (in the GGS this meant within the last three months) they had experienced the situation described as follows: a) 'I have come home from work too tired to do the chores that need to be done'; b) 'It has been difficult for me to fulfil my family responsibilities because of the amount of time I spent at my job'; c) 'I have arrived at work too tired to function well because of the household work I have done'; d) 'I have found it difficult to concentrate at work because of my family responsibilities'. Four responses were offered: 1) several times a week; 2) several times a month; 3) once or twice a month; 4) never. Given the nature of our subject, the focus is on working people living in a nuclear family, including childless couples and couples whose children do not share the same household with them. Data for this battery of questions in the GGS are available for just the Czech Republic, France, Bulgaria, and Georgia. These four countries represent distinct types in terms of their stage of economic development. The countries in this respect form a kind of scale, from France as the most advanced to Georgia as the least advanced (Georgia differs in terms of some indicators from all other countries, which influences the correlation statistics, but it is included in order to document the influence of modernisation, and also in-country inequalities as a result of the effects of mutually dependent factors).

Using the subjective assessment people make about how well they are able to manage a work-life balance, a cross-national comparison (Table 2) shows that 
Table 2. Success at maintaining a work-life balance - selected indicators

\begin{tabular}{lccccc}
\hline & $\begin{array}{c}\text { Work } \\
\text { responsibili- } \\
\text { ties }^{1)}\end{array}$ & $\begin{array}{c}\text { Responsi- } \\
\text { bilities at } \\
\text { homes) }^{2)}\end{array}$ & $\begin{array}{c}\text { General } \\
\text { index }^{3)}\end{array}$ & $\begin{array}{c}\text { Too much } \\
\text { time spent at } \\
\text { work }^{4)}\end{array}$ & $\begin{array}{c}\text { Inability to } \\
\text { concentrate }^{\text {at work }}\end{array}$ \\
\hline Men & 19.6 & 68.0 & 22.1 & 39.8 & 74.3 \\
CR & 29.2 & 76.4 & 32.6 & 59.2 & 85.3 \\
France & 19.0 & 76.9 & 22.0 & 40.8 & 85.2 \\
Bulgaria & 28.1 & 78.6 & 32.7 & 35.3 & 82.4 \\
Georgia & 0.23 & 0.13 & 0.21 & 0.21 & 0.13 \\
CN & & & & & \\
Women & 15.9 & 59.1 & 18.1 & 37.8 & 66.6 \\
CR & 24.4 & 67.5 & 25.4 & 60.0 & 78.9 \\
France & 18.3 & 64.1 & 20.3 & 38.6 & 77.3 \\
Bulgaria & 28.0 & 67.9 & 30.5 & 36.2 & 74.0 \\
Georgia & 0.23 & 0.14 & 0.23 & 0.23 & 0.12 \\
CN & & & & & \\
\hline
\end{tabular}

Notes: 1) Share of people who feel least they have difficulty coping with responsibilities at work (score for questions a and b, seven-point scale); 2) share of people who feel least they have difficulty coping with work at home (score for questions $\mathrm{c}$ and $\mathrm{d}$, sevenpoint scale); 3) share of people successful at maintaining a work-life balance according to their total score (questions a-d, five-point scale; based on the sum of points from the four questions scored from 1 to 4 ); 4) the response 'never' for question $b$; 5) the response 'never' for question d.

$\mathrm{CN}=$ contingency coefficient for differences between countries, statistically significant at 0,001 .

Source: GGS.

the differences between the four countries are not very pronounced. Moreover, countries at very different levels of economic development (France and Georgia) are closer to each other than are similarly advanced countries. In this comparison, the Czech Republic comes out as relatively less 'successful' at reconciling work and family. This seems to contradict the findings of other comparative analyses [Edlund 2007; Work-life Balance 2007; Second 2009]. However, a specific Czech feature is that, as well as having the smallest share of people who are successful at maintaining a work-life balance, it also has the smallest share of people who are least successful at doing so (e.g. 9\% of Czech men and 8\% of Czech women have difficulty with long working hours several times a week, compared to $14 \%$ and $16 \%$ of Bulgarian men and women and $19 \%$ and $20 \%$ of Georgian men and women).

A closer look that takes in socio-cultural and socio-economic distinctions reveals the differences between countries to be more pronounced. Of interest, for example, in Table 3 is the comparison of the intensity of the influence of objective 
and subjective characteristics of work. In the Czech Republic, attitudes towards work have a stronger influence, while in Georgia occupational status has a big influence. In France, where it is easier to find part-time work, working hours have a less negative impact on work-life balance (people avoid work-life conflict by adjusting their working hours).

If the hypothesis presented at the start of this section is valid, success at achieving a work-life balance should vary by individual and family characteristics. One difference that was assumed as relevant and observed as such elsewhere, that is, the difference between men and women [Crompton and Lyonette 2006; Kuchařová et al. 2009a], was not directly confirmed on the GGS data. This can be partly explained by the fact that many mothers begin working only once they are already in a situation where they can manage to combine both their work and family roles. However, it is possible to expect that there are various ways of arriving or not arriving at such a situation. In France and Georgia (countries where there is less work-family conflict) mothers return to work from parental leave earlier. However, while in France the greater availability of day care enables them to do so, in Georgia it is because the grandparents are involved in caring for grandchildren. A possible reason for the small gender difference is that job fatigue is the primary component in the indicator used to measure work-life conflict, while the effect of gender is more likely felt from an (over)load of domestic work, which is a less significant component in this indicator. Another factor in this could be that mothers of young children more often work in feminised professions, which require less of an investment of mental and physical effort and time.

In the GGS data, statistically more significant are the differences based on age, especially in France, where women return to work when their children are younger. Education level has little influence on work-life conflict (perhaps because that relates more to individual job satisfaction) and socio-professional status even less so. Among the countries in the comparison, the influence of these two factors is the weakest in the Czech Republic.

Despite the overall small differences based on gender, Table 3 presents other sources of differences for women, because we can assume that among women the differences are greater (the overall impact of parenthood on the professional life of women is greater). The duration of working hours is a factor of crucial but varying influence. A small role is played by important characteristics of the given stage in the family cycle (the number and age of dependent children), and this is related to the above-mentioned strategies that women choose for timing their return to work. The connection to the family cycle suggests that the age of the respondent has an influence, but that influence can be expressed by another determinant (the effect of career advancement, or, conversely, declining physical strength or intellectual capacity, and so on), which is confirmed by its greater influence in the case of men than women.

The sources of differentiation of work-life balance are not consistent in any of the four countries. It was also impossible to identify any groups significantly 


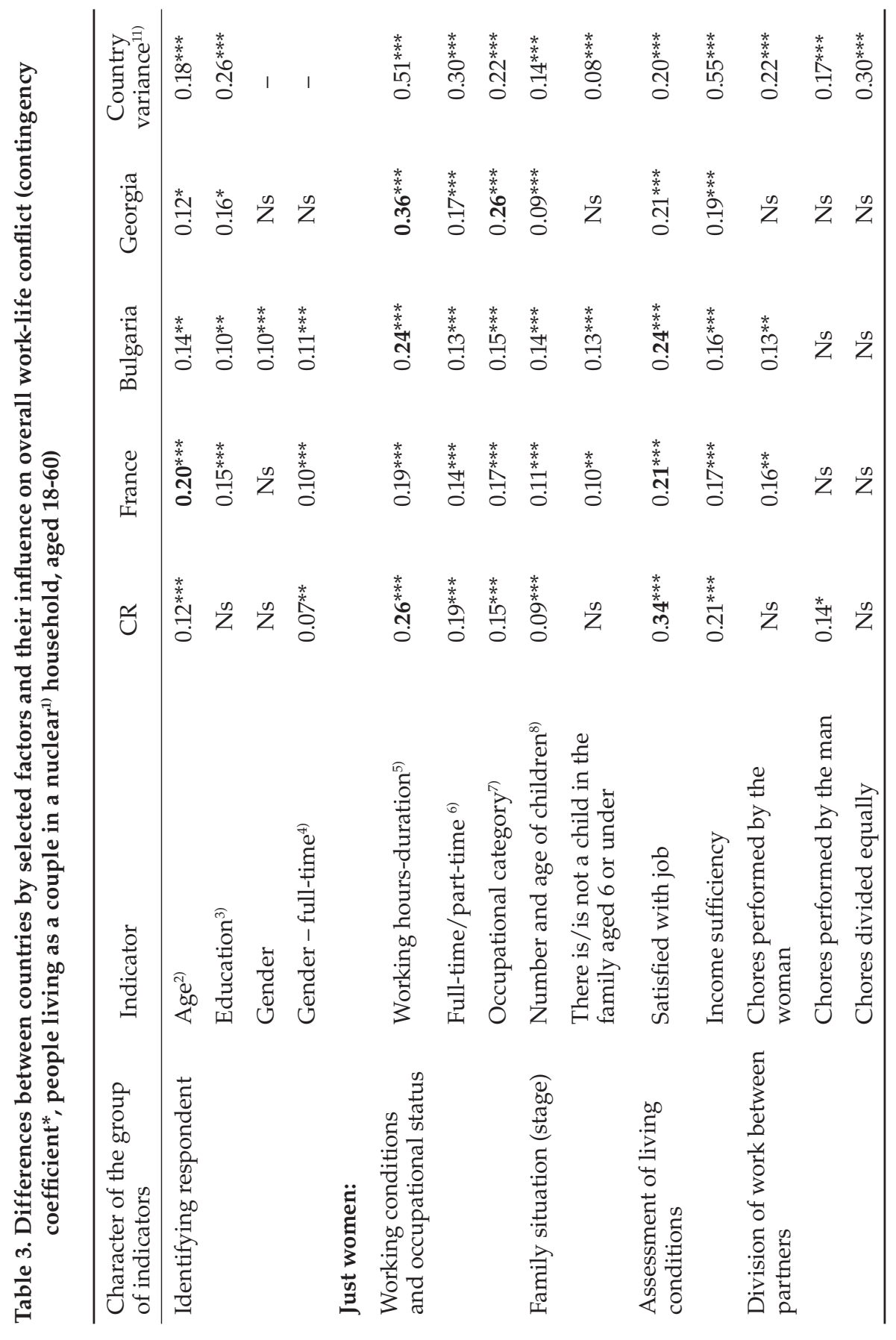




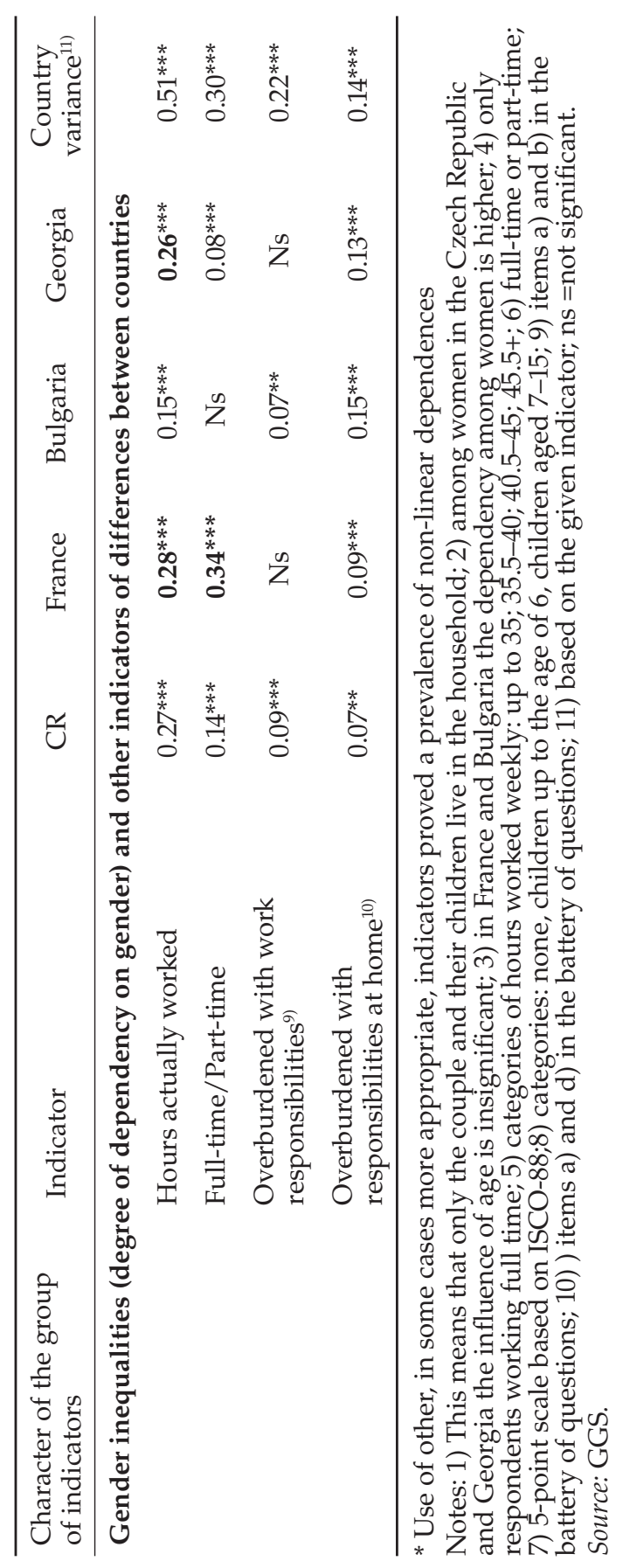


more or less successful at achieving this balance. Consequently, the analysis did not confirm either the seemingly determinant influence of structural factors on work-life balance or a sufficiently strong determinant influence of different individual dispositions.

If the significance of individual and family characteristics as differentiating factors is not statistically strong, it is possible then to look for specific national or social aspects of strategies or behavioural patterns, which are variously influenced by these characteristics. As noted above, the division of roles between partners and decisions about the economic activity of mothers in different stages of the life cycle appear to be important. The following section focuses on some of the preferred and applied strategies for combining economic activity and the demands of caring for a family in terms of timing (staging in the life cycle) and from the perspective of the division of roles. The aim is to test the assumption that the similar success at achieving a work-life balance observed in countries at different developmental stages and with different family regimes stems from the fact that the staging of the life and family cycles and the division of labour between partners vary between these countries. It is also assumed that in these aspects the effect of gender differences is stronger.

In a comparison of GGS data for selected countries, Georgia stands out most, and Bulgaria also somewhat, for their more traditional division of partner roles (Fig. 2). The smaller differences in other countries are not reflected as strongly in the specific features of their family regimes but rather in gender inequalities. The possibility of differentiating forms of role division between partners within national units was also tested. The division of labour was operationalised as the role of women in selected activities [cf. Crompton and Lyonette 2006: 386]. Social conditions could only be clearly demonstrated as determinants in Germany and Hungary. The differences observed in all the countries (statistically significant at a level of at least 0.005) were connected to socio-occupational status (Cn between 0.12 /CR/ and 0.24 /Germany/) and a woman's age (Cn from 0.13 /CR, Hungary, Germany/ to 0.23 /France/), which to some extent demonstrates the effect of the given stage in the family cycle. There were other individual differentiating factors in the different countries, but both working conditions and family situation were found to have an effect only in Germany. In the Czech Republic and the other countries, modified traditional approaches to the division of roles between partners not only prevail but are quite universal.

Data from Czech studies show a relationship between the model of role division between partners and the family cycle stage [Kuchařová et al. 2009b]. Women prefer home care for children up to three years of age (Fig. 3). Very strong agreement was found between the preferences and real behaviour of mothers. However, how well preferences correspond with reality need not be a matter of choice. Women for instance underestimate the difficulties of returning to work after a long period of parental leave [Kuchařová et al. 2006a].

It is impossible to tell from this analysis whether societal influences or pri- 
Figure 2. The division of roles at home - who in the household performs selected tasks (average value of the total index of the role of individuals in selected tasks)

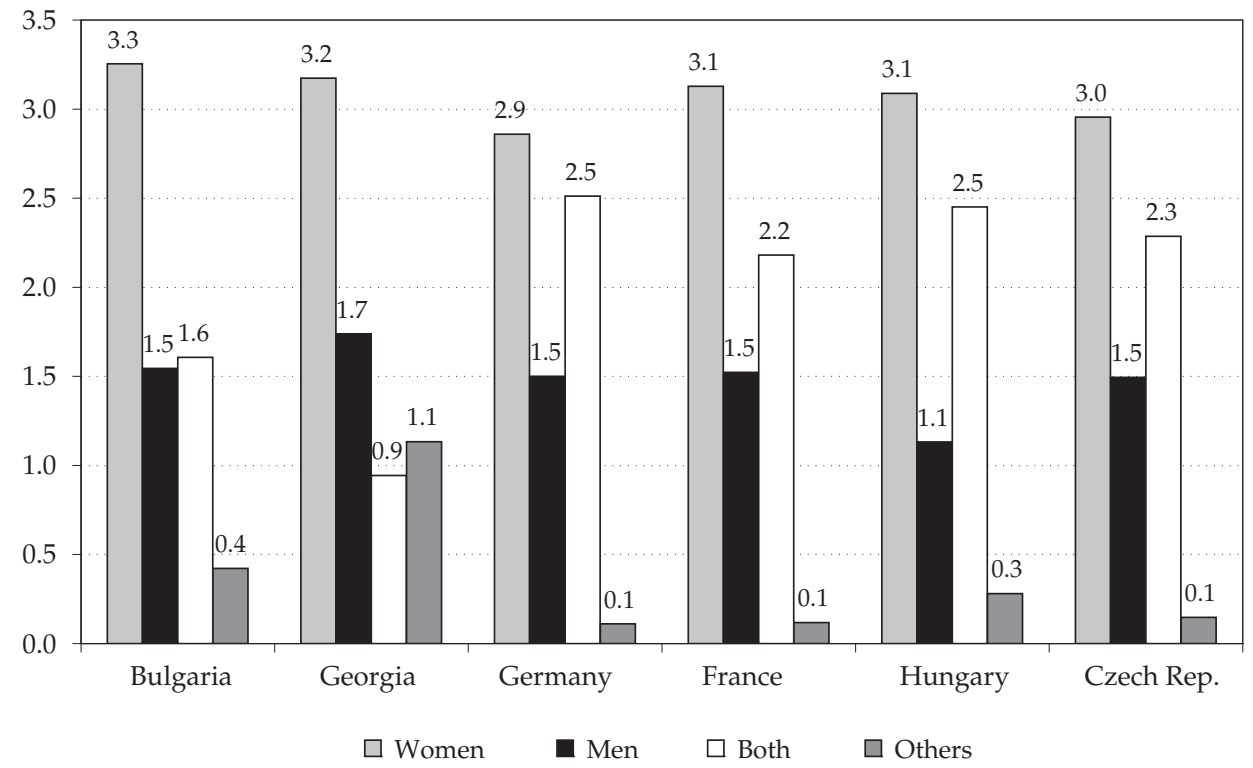

Notes: The selected tasks are cooking, washing the dishes, shopping, cleaning, minor repairs, managing household finances, and organisation of free time. The index value is the number of these tasks performed exclusively or primarily by the given person. Frequencies of activities include 0 . Differences between countries is indicated by $\mathrm{Cn}$ ranging from 0.20 to 0.29 and statistically significant at 0.001 .

Source: GGS.

vate influences have greater weight in determining work-life balance. However, what is apparent from this analysis (and other sources) is that the two groups of factors are interdependent. The significance of each group of factors also varies depending on the particular context. Private determinants clearly are of greater significance in the case of working people (parents) trying to combine work and family commitments. The way roles are divided between partners, and thus the economic activity of women, depends on the stage in the family cycle. For this aspect of work-life balance external factors are more significant, and that significance increases in later stages of the family cycle, when women want to become more active in the public sphere of life, rather than when they are caring for young children.

The effect of structural and institutional conditions, that is, of family and social policy in particular, as well as the particular conception of gender issues in a country, shape the space in which people choose their strategies for maintaining 
Figure 3. Preferred working hours of mothers and method of day care for pre-school age children by the age of the children a)

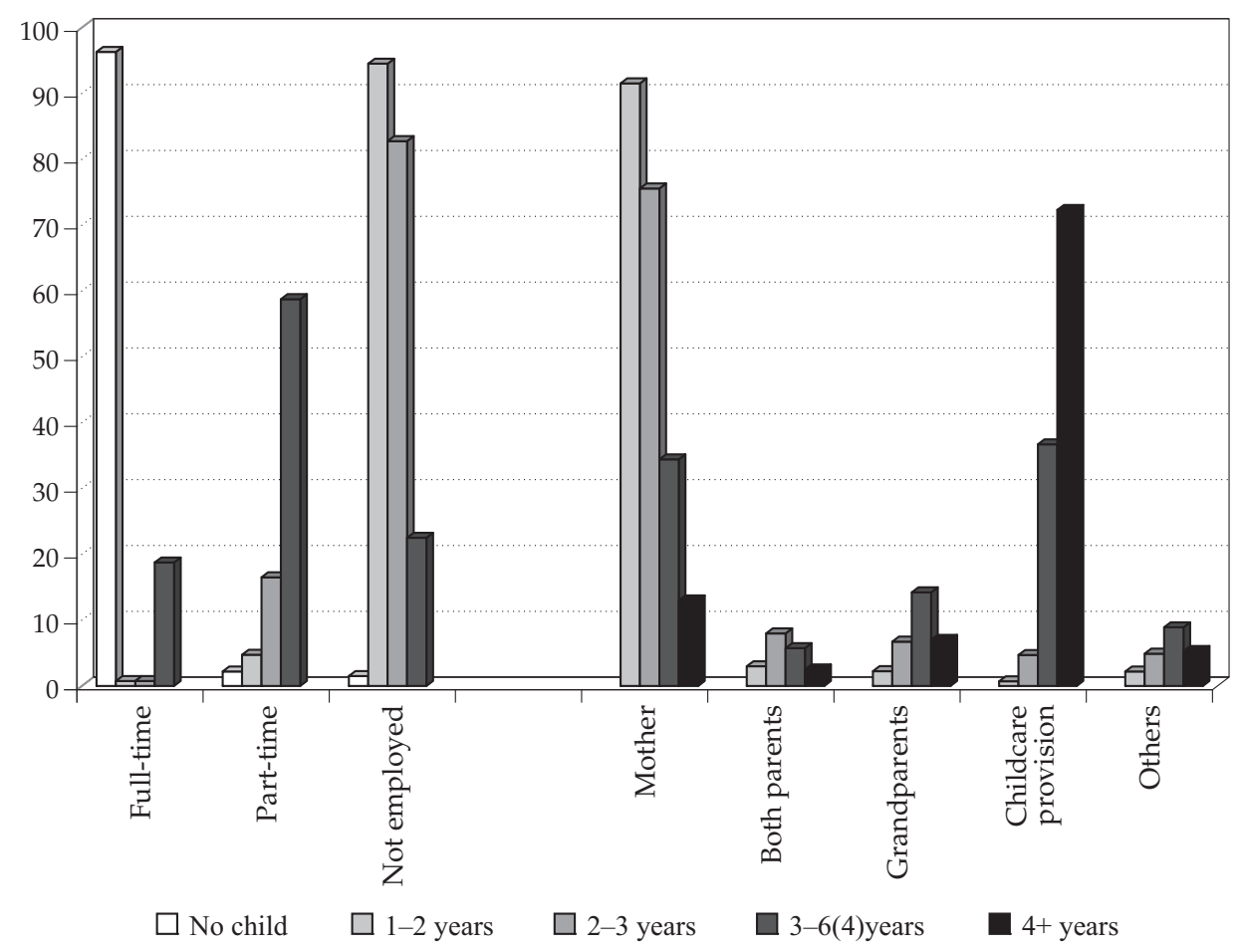

Notes: a) Opinions of mothers of children up to the age of 6 and living with a partner; b) In the legend the 3-6 interval relates to working-hour preferences, the 3-4 interval relates to childcare preferences; for the category $4+$ only childcare preferences were examined; c) Fathers were only rarely indicated as the primary carer, and therefore this alternative is ranked under 'other'.

Source: RZV 2006, survey of couples.

a work-life balance. The family regimes that emerge in this context are never (and this is demonstrated empirically on the observed countries) extreme in character, which makes it more difficult to find clear connections between family regime and the real strategies of work-life balance. Assessed from the perspective of the employment rate of women, some specific features are apparent in the Czech Republic and other countries (Table 5, cf. Table 1). In a typology of family regimes Czech family policy lies in between the market-oriented and familialistic types. It does nothing to stimulate the employment of mothers of young children because it gives little support to day care for children while offering a long period of parental leave. Although this does not put family policy in direct conflict with 
Table 5. Socio-economic status of women aged 25-54 (\%)

\begin{tabular}{lrrrrrrr}
\hline & \multicolumn{7}{c}{ Countries } \\
\cline { 2 - 8 } & France & $\begin{array}{c}\text { Nether- } \\
\text { lands }\end{array}$ & $\begin{array}{c}\text { Ger- } \\
\text { many }\end{array}$ & $\begin{array}{c}\text { Hun- } \\
\text { gary }\end{array}$ & CR & $\begin{array}{r}\text { Bul- } \\
\text { garia }\end{array}$ & $\begin{array}{c}\text { Geor- } \\
\text { gia }\end{array}$ \\
\hline Employed & 73.5 & 72.2 & 64.3 & 66.3 & 68.6 & 68.4 & 40.0 \\
Unemployed & 8.9 & 6.8 & 9.3 & 5.6 & 9.3 & 19.8 & 14.1 \\
$\begin{array}{l}\text { Maternity or } \\
\text { parental leave }\end{array}$ & 3.5 & 0.1 & 5.5 & 11.7 & 13.7 & 1.5 & 0.1 \\
$\begin{array}{l}\text { At home } \\
\text { Other }\end{array}$ & 9.2 & 9.5 & 16.6 & 3.5 & 1.8 & 8.8 & 44.1 \\
\hline
\end{tabular}

Source: GGS, data files for selected countries; $\mathrm{CN}=0.33$ statistically significant at 0.001 .

declared preferences, it has an effect on the low rate of employment of Czech mothers with young children. Nevertheless, the policy does not dramatically reduce the overall economic activity of Czech women. Generally the prevailing tendency in the Czech Republic is to use a strategy of work-life balance based on the dual-earner model, and to do so under circumstances of very limited opportunities for work flexibility. Unlike the Czech Republic, family regimes in France and the Netherlands favour a 'modernised' role division between partners, but with more women working shorter hours. In France the modernising trend in family policy is confronted by the persistence of gender differences in the division of roles (e.g. there is a greater share of women in the household there), but the female employment rate is still slightly above the EU average. In the Netherlands family policy is less pronatal, but the female employment rate is high owing to the availability of flexible working hours. Both of these factors decrease gender differences. Germany differs from both of these countries by the high proportion of people who conform to the male breadwinner model of role division between partners. Hungary, while considerably alike the Czech Republic, exhibits more traditional features in the area of gender inequalities. The specific features of the least economically developed of the countries observed - Bulgaria and Georgia - derive from the higher rate of unemployment and the closer contacts within the extended family, which make up for the less generous family and social policy.

In conformity with statistically established facts, the GGS data reveal the diversity and nationally specific nature of external conditions. The discrepancy between the existence of differences between countries and the relatively little variability in the subjective success of work-life balance that was noted above is largely explained by the differences between the strategies used to reconcile work and family commitments. These strategies reflect external, economic, and socio-cultural conditions, as demonstrated, for instance, by comparing the use of support from the extended family in traditional familialistic families (Georgia) and in the other countries, where the independence of nuclear families encour- 
ages the more equal participation of partners in the household. However, the greater participation of men may just be the result of changes at the subjective level and societal factors. This is illustrated, for example, by comparing countries that provide similar support for the employment of mothers but between which the participation of fathers varies (Nordic countries and France). The existence of a traditional division of roles thus cannot just be ascribed to insufficient change required to alter external conditions, as it is also maintained by continued adherence to traditional patterns of behaviour. However, the strategies used to reconcile work and family in specific situations in life are not grounded entirely in free choice (e.g. the timing of parental leave, the choice of work regime, interrupting the professional careers of fathers when a gender wage gap exists).

\section{Conclusion}

Two objectives were laid out at the opening of this article. The first was to assess the success of work-life balance in relation to structural-institutional conditions. The subjective assessment of conflict between work and family roles proved to be lower than might have been expected given the high demands placed on both spheres of life today. At the same time, the differences expected to exist between countries with different modernisation features and family regimes were not confirmed. More significant differences were observed in the success of maintaining a work-life balance when assessed according to the rate of economic activity. While external conditions are not the decisive factors in the relationship between work and family roles, their influence on the decision whether to fulfil one's professional ambitions (or otherwise motivated economic activity) while at the same time performing one's parental responsibilities is most evident in those stages of the family cycle when the relationship between family and work is the most complicated (during the period of caring for young children). Empirical data and the findings of other authors moreover suggest that the effect of structural-institutional factors is more complex. The effects of individual external factors can interact specifically in different countries.

Given the results for the first objective, it was impossible in this article to arrive at any clear-cut conclusions even for the second objective, which was to assess the effect of private and structural-institutional determinants on the success of work-life balance. The hypothesis more closely specified that the effect of external conditions is modified in different countries by the specific circumstances of private life and socio-cultural customs (an example being the difficulty in reality of fathers going on parental leave). Despite the lack of strong statistical conclusiveness, the hypothesis can be regarded as having a high probability. Based on the observed degree of differences between individual countries, the effect of external factors is limited and transformed by the effect of other factors. However, the opposite also applies: individual and subjective factors are to a certain degree influenced by external factors. 
The behaviour of people who find themselves in a situation of work-life conflict is driven by the pressure of conditions in the labour market and by the given socio-economic situation, which are circumstances that are variable over time. This also makes assessing the complex of external factors more difficult.

These findings show that when analysing the role of external conditions and the factors of private life it is necessary to distinguish between two principal aspects of work-life balance. One is the staging of the life cycle in terms of the performance of work and childcare and the second is the interconnection of the two spheres in the lives of working parents. These are intertwined, but not necessarily interdependent. For example, the conflict between work and family can be reduced by exiting the labour market during the period of providing care for (very young) children (a 'lifetime' strategy), but even people who in this stage of the family cycle choose to be economically active need not necessarily experience conflict between the two spheres (the strategy of the parallel performance of both roles).

Mention was made in the introduction of the significance of work-life balance from three perspectives: employment, gender, and fertility. In these respects there are specific features to the success of work-life balance in the Czech Republic. With regard to supporting employment, the two barriers to this in the Czech Republic (limited availability of childcare and the long period of parental leave [e.g. Lewis, Campbell and Huerta 2008; Kangas and Rostgaard 2007]) are 'offset' by the high rate of economic activity among mothers with older children. Conversely, given that the demand for atypical working hours remains unmet in reality (including the demand for part-time work, and not just for women), it can be assumed that women's employment in the Czech Republic would receive a boost from more effective measures directed at supporting work flexibility.

From the perspective of gender equality in the Czech Republic there is a high degree of identification with the current state of the division of family and work roles between partners [cf. Höhne, Svobodová and Štastná 2008] and thus with the space in which work and family responsibilities are combined. These realities put no pressure 'from below' on the relevant subjects, in particular employers and local authorities, to give more support to attaining greater gender equality. If people do not see much of a conflict in the relationship between private and working life (as shown above), they also have little sense of the negative aspects of gender inequalities.

Nor are there high expectations for improvements to the effectiveness of the tools of social support for work-life balance in the interest of enhancing fertility in the Czech Republic if a broad spectrum of conditions to back this are not created. The higher rate of fertility today compared to the 1990s is only to a small degree the product of advancements in the tools of work-life balance [cf. Sobotka et al. 2008]. Many analyses have pointed out that measures promoting a work-life balance alone are insufficient to bring about a rise in fertility [e.g. Kotowska and Matysiak 2008; Haberlová and Kuchařová 2008]. 
VĚRA KUCHAŘOVÁ is a senior researcher in the Research Institute for Labour and Social Affairs. She is head of the research group for family policy. She specialises mainly in sociology of the family, family and social policy, and demographic behaviour. Recently she has published monographs (as a co-author or editor) and articles on work-life balance, the living conditions of Czech families, and family policy.

\section{References}

A New Organisation of Time over Working Life. 2003. Dublin: European Foundation for the Improvement of Living and Working Conditions.

Babies and Bosses - Reconciling Work and Family Life: A Synthesis of Findings for OECD Countries. 2007. Paris: OECD.

Benn, N. V. and J. Kvist. 2007. Working and Parenting. The Effects of Having Children on Working Time in Six European Countries. 5th International Research Conference on Social Security. International Social Security Association. Retrieved 20 August 2009 (http://www.issa.int/aiss/Resources/Conference-Reports/Working-and-parenting).

Berger, P. L. and B. Berger. 1983. The War over the Family, Capturing the Middle Ground. New York: Penguin Books.

Botev, N. 2008. "“Can Policies Enhance Fertility in Europe?" and Questions Beyond.' Pp. 29-34 in Vienna Yearbook of Population Research. Vienna: Vienna Institute of Demography.

Česká republika v mezinárodním srovnání 2008 (vybrané údaje). (Czech Republic in an International Comparison - selected data) 2008. Prague: ČSÚ. Retrieved 27 November 2009 (http://www.czso.cz/csu/2008edicniplan.nsf/p/1607-08).

Chorvát, I. 2006. 'Rodinné vztahy, väzby a perspektívy na pozadí procesu modernizácie.' (Family Relationships, Ties and Perspectives against the Backdrop of the Modernisation Process) Pp. 8-21 in Životní cyklus. Sociologické a demografické perspektivy, edited by D. Hamplová, P. Šalamounová and G. Šamanová. Prague: Sociologický ústav AV ČR.

Crompton, R. and C. Lyonette. 2006. 'Work-Life "Balance" in Europe.' Acta Sociologica 49 (4): 379-393.

D'Addio, A. C. and M. M. D'Ercole. 2005. Trends and Determinants of Fertility Rates in OECD Countries: The Role of Policies. Paris: OECD Social, Employment and Migration Papers.

de Singly, F. 1999. Sociologie současné rodiny. (Sociology of the Contemporary Family) Prague: Portál.

Edlund, J. 2007. 'The Work Family Squeeze: Conflicting Demands of Paid and Unpaid Work among Working Couples in 29 Countries.' International Journal of Comparative Sociology 48 (6): 451-480.

Esping-Andersen, G. 2002. Why We Need a New Welfare State. Oxford, New York: Oxford University Press.

Feasibility Study on the Availability of Comparable Child Care Statistics in the European Union. EUROSTAT. 2002. Retrieved 27 December 2009 (http://epp.eurostat.ec.europa.eu/ cache/ITY_OFFPUB/KS-CC-02-001/EN/KS-CC-02-001-EN.PDF).

Gauthier, A. H. and D. Philipov. 2008. 'Can Policies Enhance Fertility in Europe?' Pp. 1-16 in Vienna Yearbook of Population Research. Vienna: Vienna Institute of Demography.

Gershuny, J. 2000. Changing Times. Work and Leisure in Postindustrial Society. Oxford: Oxford University Press. 
Gershuny, J. 2003 'Time, through the Lifecourse, in the Family.' Working Papers of the Institute for Social and Economic Research 2003-3. Colchester: University of Essex.

Haberlová, V. and V. Kuchařová. 2008. 'Rodina a zaměstnání v průběhu životního cyklu.' (Family and Work in the Course of the Life Cycle) Pp. 19-62 in Rodina, děti a zaměstnání v České společnosti, edited by Tomáš Sirovátka and Ondřej Hora. Brno: František Šalé-Albert.

Hakim, C. 2000. Work-Lifestyle Choices in the 21st Century: Preference Theory. Oxford: Oxford University Press.

Hamplová D., P. Šalamounová and G. Šamanová (eds.). 2006. Životní cyklus. Sociologické a demografické perspektivy. (The Life Cycle: Sociological and Demographic Perspectives) Prague: Sociologický ústav AV ČR.

Hardarson, O. 2007. 'The Flexibility of Working Time Arrangements for Women and Men. EUROSTAT.' Statistics in Focus 96/2007. Retrieved 7 December 2009 (http://epp.eurostat.ec.europa.eu/cache/ITY_OFFPUB/KS-SF-07-096/EN/KS-SF-07096-EN.PDF).

Hoem, J. M. 2006. 'Proč má Švédsko tak vysokou porodnost?' (Why Sweden Has a High Fertility Rate) Demografie 48 (4): 241-250.

Höhne, S., K. Svobodová and A. Stáastná. 2008. 'Význam partnerství pro harmonizaci rodiny a zaměstnání.' (The Significance of Partnership for Harmonising Work and Family) Pp. 119-144 in Rodina, děti a zaměstnání v České společnosti, edited by T. Sirovátka and O. Hora. Brno: František Šalé-Albert.

Kangas, O. and T. Rostgaard. 2007. 'Preferences or Institutions? Work-family Life Opportunities in Seven European Countries.' Journal of European Social Policy 17 (3): 240-256.

Kocourková, J. and L. Rabušic (eds.). 2006. Sňatek a rodina: zájem soukromý nebo veřejný? (Marriage and the Family: A Private or Public Concern?) Prague: Přírodovědecká fakulta UK.

Kotowska, Irena E. and Anna Matysiak. 2008. 'Reconciliation of Work and Family Within Different Institutional Settings.' Pp. 299-318 in People, Population Change and Policies, edited by Charlotte Höhn, Dragana Avramov and Irena E. Kotowska. Hague: Springer.

Kř́žzová, A. (ed.), H. Maříková, H. Hašková, J. Bierzová. 2006. Pracovní a rodinné role a jejich kombinace v životě rodičü: plány versus realita. (Work and Family Roles and Their Combination in Family Life: Plans versus Reality) Prague: Sociologický ústav AV ČR.

Kuchařová, Věra. 2008. ‘Harmonizace rodiny a zaměstnání podle formy rodinného soužití.' (Work-life Balance by Forms of Family Cohabitation) Forum sociální politiky 2 (6): 8-14.

Kuchařová, V., S. Ettlerová, O. Nešporová, K. Svobodová. 2006a. Zaměstnání a péče o malé děti z perspektivy rodiču a zaměstnavatelü: Uplatnění nárokü na rodičovskou dovolenou a na volno na péči o nemocného člena rodiny v praxi. (Work and Care for Small Children from the Perspective of Parents and Employers: Claiming Parental Leave and Time Off to Care for a Sick Family Member) Prague: Výzkumný ústav práce a sociálních věcí.

Kuchařová, V., S. Ettlerová, B. Matějková, K. Svobodová and A. Štastná. 2006b. Postoje a zkušenosti s harmonizací rodiny a zaměstnání rodiču dětí předškolního a mladšího školního věku. (Attitudes towards and Experiences with Work-life Balance among Parents of Pre-schoolers and Young School-Age Children) Prague: Výzkumný ústav práce a sociálních věcí.

Kuchařová, V. et al. 2009a. Péče o děti předškolního a raného školního věku. (Caring for Pre-schoolers and Young School-Age Children) Prague: Výzkumný ústav práce a sociálních věcí. 
Kuchařová, V. (ed.), S. Höhne, K. Svobodová and A. Štastná. 2009b. Rodina, zaměstnání a vzdělání. (Family, Work, and Education) Prague: Výzkumný ústav práce a sociálních věcí.

Lewis, J., M. Campbell and C. Huerta. 2008. 'Patterns of Paid and Unpaid Work in Western Europe: Gender, Commodification, Preferences and the Implications for Policy.' Journal of European Social Policy 18 (1): 21-37.

Maříková, H. (ed.) 2000. Proměny současné české rodiny: Rodina - gender - stratifikace. (Family - Gender - Stratification) Prague: Sociologické nakladatelství.

Maříková, H. 2008. 'Mateřství, rodina a práce z pohledu matek malých dětí.' (Maternity, Family and Work from the Perspective of Mothers of Young Children) Signs: Gender, rovné príležitosti, výzkum 9 (2): 45-55.

Maříková, H. and M. Vohlídalová. 2007. Trvalá nebo dočasná změna? Uspořádání genderových rolí v rodinách s opečujícimi otci. (Permanent or Temporary Change? The Arrangement of Gender Roles in Families with Caregiving Fathers) Prague: Sociologický ústav AV ČR.

Matějková, B. and J. Paloncyová. 2005. Rodinná politika ve vybraných evropských zemích s ohledem na situaci $v$ České republice. (Family Policy in Selected European countries with a View to the Situation in the Czech Republic) Brno: Masarykova universita - Prague: Výzkumný ústav práce a sociálních věcí.

Matějů, P. and J. Večerník. 1998. Zpráva o vývoji české společnosti 1989-1998. (A Report on the Development of Czech Society 1989-1998) Prague: Academia.

Modernising Social Policy for the New Life Course. 2007. Paris: OECD.

Možný, I. 1990. Moderní rodina: Mýty a skutečnost. (The Modern Family: Myths and Reality) Brno: Blok.

Možný, I. 2003. 'Modernizace české rodiny a mezigeneračních vztahů v mezinárodním srovnání.' (The Modernisation of the Czech Family and Intergenerational Ties in an International Comparison) Pp. 11-36 in Modernizace a česká rodina, edited by P. Mareš and T. Potočný. Brno: Barrister \& Principal.

Možný, I. 2008. Rodina a společnost. (Family and Society) Prague: Sociologické nakladatelství.

Národní koncepce rodinné politiky. (The National Concept of Family Policy) 2005. Prague: Ministerstvo práce a sociálních věcí. Retrieved 8 September 2009 (http://www.mpsv. $\mathrm{cz} /$ files/clanky/2125/koncepce_rodina.pdf).

Nešporová, O. 2005. Rodiny s otci na rodičovské dovolené. (Family with Fathers on Parental Leave) Prague: Výzkumný ústav práce a sociálních věcí.

Nešporová, O. 2006. 'Rodinná politika.' (Family Policy) Pp. 81-90 in Socioekonomické hodnoty, politiky a instituce v období vstupu České republiky do Evropské unie, edited by Z. R. Nešpor and J. Večerník. Prague: Sociologický ústav AV ČR.

Nešporová, O. 2007. 'Měnící se rodičovství v kontextu podmínek na trhu práce.' (Changing Parenthood in the Context of Labour Market Conditions) Fórum sociální politiky 1 (2): 13-17.

Neyer, G. 2006. 'Family Policies and Fertility in Europe.' MPIDR Working Paper 2006-10. Rostock: MPIDR.

OECD Family Database. 2007. OECD, Social Policy Division, Directorate of Employment, Labour and Social Affairs. [Database] Retrieved 7 November 2009 (www.oecd.org/ els/social/family/database).

Organizace práce a uspořádání pracovní doby podle výsledků ad hoc modulu 2004 výběrového šetření pracouních sil. 2005. Prague: ČSUU.

Rabušic, L. and B. E. Chromková Manea. 2007. 'Preferenční teorie Hakimové v českém kontextu.' (Hakim's Preference Theory in the Czech Context) Demografie 49 (2): 77-86. 
Rychtaříková, J. 2008. 'Česká republika: trendy demografického vývoje.' (Czech Republic: Trends in Demographic Development) Pp. 11-41 in Partnerství, rodina a mezigenerační vztahy $v$ české společnosti, edited by J. Rychtaříková and V. Kuchařová. Prague: Přírodovědecká fakulta UK and Výzkumný ústav práce a sociálních věcí.

Saraceno, C. 2009. Between Care Needs and Equal Opportunity Goals, for Women but also Children. Paper presented at the international conference 'Parental Childcare and Employment Policy', in Prague on 5-6 February 2009. Retrieved 7 November 2009 (http://www.mpsv.cz/cs/6390).

Second European Quality of Life Survey. 2009. Dublin: European Foundation for the Improvement of Living and Working Conditions.

Sirovátka, T. 2006. 'Rodina a reprodukce versus zaměstnání a role sociální politiky.' (Family and Reproduction versus Work and the Role of Social Policy) Pp. 77-112 in Rodina, zaměstnání a sociální politika, edited by T. Sirovátka. Brno: Fakulta sociálních studií MU.

Sirovátka, T. and H. Bartáková. 2008. ‘Harmonizace rodiny a zaměstnání v České republice a role sociální politiky.' (Harmonisation of Family and Work in the Czech Republic and the Role of Social Policy) Pp. 63-96 in Rodina, děti a zaměstnání v České společnosti, edited by T. Sirovátka and O. Hora. Brno: František Šalé-Albert.

Sobotka, T., A. Štastná, K. Zeman, D. Hamplová and V. Kantorová. 2008. 'Czech Republic: A Rapid Transformation of Fertility and Family Behaviour after the Collapse of State Socialism.' Demographic Research 19 (19): 401-454.

The Social Situation in the European Union 2005-2006. 2006. EUROSTAT. Retrieved 7 November 2009 (http://epp.eurostat.ec.europa.eu/cache/ITY_OFFPUB/KE-AP-06001/EN/KE-AP-06-001-EN.PDF).

Sullerot, E. 1998. Krize rodiny. (The Crisis of the Family) Prague: Karolinum.

Švarc, P. and N. Švarcová. 2007. 'The Impact of Social and Tax Policies on Families with Children: Comparative Study of the Czech Republic, Hungary, Poland and Slovakia.' IES Working Paper 28/2007. IES FSV. Charles University. Retrieved 20 May 2009 (http://ies.fsv.cuni.cz/sci/publication/show/id/3286/lang/cs).

Thévenon, O. 2008. ‘Family Policies in Europe: Available Databases and Initial Comparisons.' Pp. 165-177 in Vienna Yearbook of Population Research. Vienna: Vienna Institute of Demography.

Večerník, J. 2009. 'Le revenu des ménages en République Tchèque après 1989: hausse et changement de structure des inégalités.' Revue d'études comparatives Est-Ouest 40 (1): 175-196.

Work-life Balance - Solving the Dilemma. 2007. Dublin: European Foundation for the Improvement of Living and Working Conditions. 


\section{Data sources}

GGS: Men and women in the Czech Republic: Life courses and intergenerational relations (GGS: Generations and Gender Survey). International longitudinal study conducted under the PAU-UNECE programme. Data collection was carried out in the Czech Republic in 2005 on a representative sample of 10006 people between the ages of 18 and 79. The size of national samples in the GGS:

\begin{tabular}{lcc}
\hline Country & Sample & Sample of couples (both partners working) \\
\hline CR & 10006 & 2907 \\
Bulgaria & 12858 & 3302 \\
France & 10079 & 2815 \\
Georgia & 11027 & 1447 \\
Hungary & 13540 & 3334 \\
Germany & 10017 & 2506 \\
Netherlands & 8161 & 2475 \\
Total & 75688 & 18786 \\
\hline
\end{tabular}

RZV: 'Family, Work and Education'. Empirical studies of selected types of family in different stages of the family cycle were carried out using quota sampling between February and April 2006 on samples of 500 respondents, one on a sample of 400 couples with young children. The types of families observed were: young childless couples, couples with children under the age of 7, married parents of school-age children, and parents whose children have left home. 